\title{
Antibiotic Resistance Profile and Chemical Quality Assessment of Ground water Sources from Periurban Area of Bucharest, Romania
}

\author{
FLORICA MARINESCU*, MIHAELA ILIE, GINA GHITA, IOANA SAVIN, CARMEN TOCIU, ANA MARIA ANGHEL, \\ ECATERINA MARCU, IULIANA MARCUS \\ National Institute for Research and Development in Environmental Protection, 294 Splaiul Independentei, 060031, Bucharest, \\ Romania
}

\begin{abstract}
Twenty-two groundwater sources mainly used for drinking purpose in Bucharest peri-urban area were investigated for assessment of physico-chemical and microbiological quality with a view to determining its potential risk to public health. Results of chemical analysis revealed that nitrites, sulphates and chlorides were below the permissible levels, while $63.64 \%$ of the analysed groundwater sources exceeded the maximum admissible concentration for nitrates, with concentration variations ranging from 67.27 to 523.19 $\mathrm{mg} / \mathrm{L}$. The bacteriological analysis showed that in about $63 \%$ of groundwater sources total coliform, faecal coliform and enterococci have exceeded the threshold limits recommended by the Drinking Water Directive 98/83/EC and the Romanian Law. Another aim of the study was to investigate the prevalence of antibiotic resistance among Gram-negative strains isolated from ground water sources. There observed the resistance to many antibiotics, particularly: ticarcillin (80\%), aztreonam (29\%), gentamicin (11\%), imipenem (9\%), ceftriaxone (9\%), ceftazidime (3\%) and ciprofloxacin (3\%). Significanthigher resistance rates were observed in strains isolated from shallow groundwater sources as compared with strains isolated from deep groundwater sources. Pseudomonas sp. (26\%) isolates with multiple-drug resistance (MDR) were encountered. The results of the study revealed a bacteriological contamination and high levels of nitrate concentrations in most of the groundwater samples, which could pose an important risk to human health.
\end{abstract}

Keywords: bacterial resistance, groundwater, antibiotics, nitrate, waterborne diseases

Groundwater represents an important source of drinking water and most of health problems related to water consumption have been linked to microbial contamination $[1,2]$, but serious health problems can also arise due to the chemical pollution as a result of recent or past human activities [3,4].

The quality of drinking water has always been a major health concern, especially in most of the developing countries where about $80 \%$ of the disease cases are associated to inappropriate sanitation and use of polluted water [5]. World Health Organization estimated that these illnesses cause 4 billion cases of diarrhoea and 2.2 million deaths annually [6]. Furthermore, pollution of groundwater by microbial contaminants of faecal origin not only leads to spread of waterborne infections, but also involves the spread of antibiotic resistant organisms into environment [7] which is a matter of concern as it can lead to transmission of antibiotic resistance to pathogenic bacteria $[8,9]$. The studies developed in the last decades showed an increase in drug resistance in waterborne pathogens against the commonly used antibiotics for the treatment of enteric diseases including tetracycline, erythromycin, ampicillin and cotrimoxazole [10]. Furthermore, resistance to third generation cephalosporins and aztreonam has progressively increased in Romania after their introduction in therapy and over a 10-year interval, the percentage of isolates resistant to ceftazidime has doubled [11].

Besides microbial agents, contaminations of groundwater resources with chemical pollutants, have received particular concern. Nitrate is believed to be the most widely spread groundwater contaminant worldwide, primarily as a consequence of agricultural activities, including excessive application of inorganic nitrogenous fertilizers and manures $[12,13]$. Other important anthropogenic sources of groundwater contamination with nitrogen are the discharge of wastewater by centralized and individual systems, leaking from underground pipelines/sew ers and leachate generated from landfills [14,15]. It is also reported that the presence of nitrate or ammonium in groundwater might be indicative of pollution by sewage or organic waste but, generally, the pollution would have occurred at a remote location or at an earlier moment than the point/ time of sampling $[16,17]$. As to the effects of nitrates on human health, two important aspects must be taken into account, namely the occurrence of methemoglobinemia and cancer risk [13].

This study was focused on the assessment of microbiological and physico-chemical groundwater quality within a periurban area of Bucharest (Romania), included by the national environment authorities on the list of vulnerable areas to nitrate pollution from agriculture sources. Another aim of the study was to investigate the prevalence of antibiotic resistance among Gram-negative strains isolated from the analysed groundwater sources.

\section{Experimental part}

Sample Collection. A total of 22 groundwater sources mainly used for drinking purpose in Bucharest periurban area (Branesti) were investigated during October November 2016 (Figure 1). The studied area is located in the Southern part of Romania, close to an important urban area (Bucharest) and it was included by the national authority for the environment [18] on the list of vulnerable areas to nitrate contamination from agriculture sources, according to EU Nitrates Directive 91/676/CEE [19]. The main economic activity within the studied area was agriculture, but, in the last years, the agricultural surface decreased, as a result of the development of construction projects. Groundwater samples were taken from wells with depth between 4 and $150 \mathrm{~m}$, most of them (about 


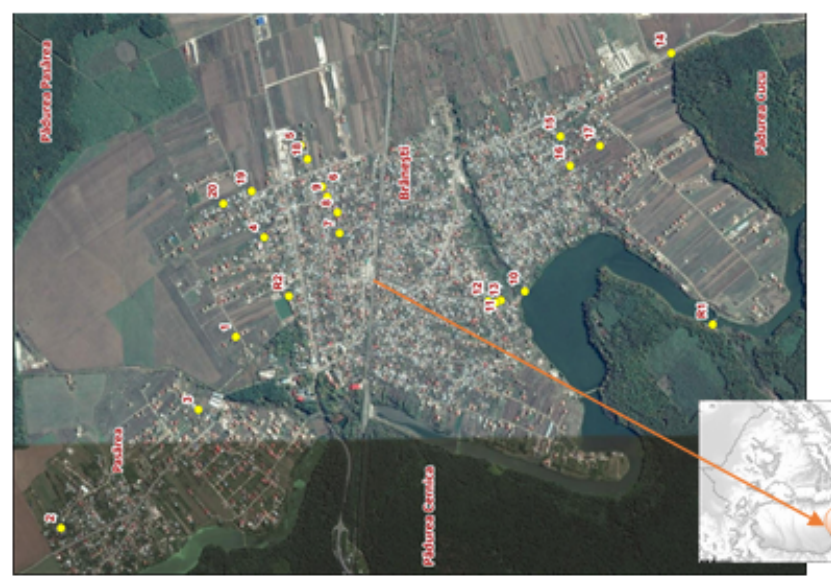

$68 \%$ ) being collected from wells with depths of $10-20 \mathrm{~m}$, shallow groundwater being the most common source of drinking water in the area. Three replicate samples were collected for the analysis, from each of water sources.

\section{Physico-chemical parameters}

Groundwater samples for physico-chemical analysis were collected according to SR EN ISO 5667-11/2000 [20] and SR EN ISO 5667-3/2013 [21]. Samples were collected and stored during transportation in labelled metal-free $2 \mathrm{~L}$ polypropylene bottles prior to be prepared and analysed. The $\mathrm{pH}$ was measured by directreading in the water sample using a multi-parameter (CONSORT C830) (SR ISO 10523) 2009) [22], being able to measure also the conductivity (SR EN ISO 27888/1997) [23]. The procedure for determining the main quality parameters was followed as per standard methods of analysis, namely the determination of the ammonia (SR ISO 5664/2001) [24], nitrates (SR ISO 7890-3/2000) [25], nitrites (SR EN ISO 26777/2002) [26], sulphates (STAS 8601/1970) [27], chlorides (SR ISO 9297/2011) [28], iron and manganese (SR EN ISO 15586/2004) [29] (HRCSAAS ContrAA 700, Analytik Jena).

\section{Bacteriological parameters}

Groundwater samples $(250 \mathrm{ml}$ ) for bacteriological analysis were collected according to ISO 19458/2006 [30] using sterile glass bottles. Samples were stored in cold bags at $4^{\circ} \mathrm{C}$ and transported to the laboratory for analysis within $6 \mathrm{~h}$ from collection. The quantitative analysis was based on membrane filtration method according to standard protocol, namely: total coliforms, Escherichia coli (SR EN ISO 9308-1:2004/AC/2009) [31] and enterococci (SR EN ISO 7899-2/2002) [32]. The total heterotrophic bacteria growing at $37^{\circ} \mathrm{C}$ was determined by standard inoculation method (SR EN ISO 6222/2004) [33]. Bacterial colonies were counted using the general guidance on the enumeration of microorganism by culture (SR EN ISO 8199/ 2008) [34].

\section{Antibiotic susceptibility testing}

The investigation of the prevalence of antibiotic resistance in the groundwater samples was performed on non-enteric Gram-negative strains, which were established to be ubiquitous bacterial species in groundwater sources [12]. Representative colonies were randomly selected from each sample and were purified on Trypticase soy agar. The bacterial isolates were further identified by biochemical tests - API 20NE (bioMérieux). Antibiotic susceptibility testing was performed by agar disk diffusion in accordance with the Clinical and Laboratory Standards Institute (CLSI 2011) [35] recommendations, using standard discs (bioMérieux) for different groups of Gram-
Fig. 1. Locations of the sampling points (Bucharest periurban area)
I egative bacteria, i.e.: ticarcillin (TIC), piperacillin (PIP), piperacillin-tazobactam (TZP), aztreonam (ATM), imipenem (IMP), ceftriaxone (CRO), ceftazidime (CAZ), cefepim (FEP), amikacin (AN), tobramycin (NN), gentamicin (GM), ciprofloxacin (CIP) and colistin (CL). After $24 \mathrm{~h}$ of incubation at $37^{\circ} \mathrm{C}$, organisms were classified as sensitive $(S)$, intermediate (I) or resistant $(R)$ based on CLSI break points. Intermediate strains were included in the resistant class.

\section{Results and discussions}

\section{Physico-chemical paramaters}

The physico-chemical characteristics of the groundwater samples are presented in Table 1. The evaluation of results was made based on the Drinking Water Directive 98/83/EC (DWD) [36] and the Romanian Law no. 458/2002 (republished in 2011) limits [37].

The $\mathrm{pH}$ of groundwater samples ranged from 7.03-8.05, values that fall within the permissible level. Any alteration in water $p H$ is accompanied by the change in other physicochemical parameters [38]. A low $\mathrm{pH}$ level of water can increase the capacity of water to attack geological material and leach toxic trace metals into water, making it potentially harmful for human consumption [39]. Additionally, acidity can cause water, a metallic or sour taste, thus the consumers may suffer some taste problem [40]. Electric conductivity (EC) values were generally below the permissible levels, except for one sample (no. 13). Electric conductivity is directly related to the presence of dissolved salts such as sodium chloride and potassium chloride [41]. A high variability in conductivity values over time may indicate changing water quality, sources of conductivity being natural or synthetic dissolved substances [12].

A number of chemical parameters such as chloride and sulphate had values below the permissible levels. The values obtained for ammonia were generally lower than the permissible level, except for one sample (no. 9). Total iron and manganese values were higher than permissible level in three groundwater samples (no. 9, 10, 12), the remaining water samples had lower values. The amount of iron in water varies depending on the geology of the area [42] and other chemical constituents of water. Manganese occurs naturally in many surface water and groundwater sources and in soil, but human activities are also responsible for manganese contamination in groundwater [43].

Nitrite $\left(\mathrm{NO}_{2}^{-}\right)$concentrations in groundwater samples were all below the recommended limits of $0.5 \mathrm{mg} / \mathrm{L}$. However, nitrate concentrations ( $\mathrm{NO}_{3}^{-}$) found in $63.64 \%$ of groundwater sources were above the maximum admissible limits of $50 \mathrm{mg} / \mathrm{L}$ recommended by both DWD and the Romanian Law, with variation of the 
Table 1

VALUES OF PHYSICO-CHEMICAL PARAMETERS IN GROUNDWATER SAMPLES

\begin{tabular}{|c|c|c|c|c|c|c|c|c|c|c|}
\hline $\begin{array}{c}\text { Sample } \\
\text { no. }\end{array}$ & $\begin{array}{l}\text { Well } \\
\text { depth } \\
\text { (m) }\end{array}$ & $\begin{array}{c}\mathrm{pH} \\
\text { (unit.pH) }\end{array}$ & $\begin{array}{l}\text { Cond. } \\
(\mu \mathrm{S} / \mathrm{m})\end{array}$ & $\begin{array}{c}\mathrm{NH}_{4}^{+} \\
(\mathrm{mg} / \mathrm{L})\end{array}$ & $\begin{array}{c}\mathrm{NO}_{2}^{-} \\
(\mathrm{mg} / \mathrm{L})\end{array}$ & $\begin{array}{c}\mathrm{NO}_{3}^{-} \\
(\mathrm{mg} / \mathrm{L})\end{array}$ & $\begin{array}{c}\mathrm{SO}_{4}^{-} \\
(\mathrm{mg} / \mathrm{L})\end{array}$ & $\begin{array}{c}\mathrm{Cl}^{-} \\
(\mathrm{mg} / \mathrm{L})\end{array}$ & $\begin{array}{c}\mathrm{Fe} \\
(\mathrm{mg} / \mathrm{L})\end{array}$ & $\underset{(\mathrm{mg} / \mathrm{L})}{\mathrm{Mn}}$ \\
\hline 1 & 40 & 7.20 & 961 & 0.005 & 0.001 & 77.62 & 7.04 & 19.85 & 0.0093 & 0.0004 \\
\hline 2 & 4 & 7.12 & 2,450 & 0.039 & 0.002 & 431.78 & 59.83 & 153.16 & 0.0040 & 0.0005 \\
\hline 3 & 30 & 7.36 & 808 & 0.006 & 0.001 & 29.90 & 15.22 & 12.05 & 0.0118 & 0.0005 \\
\hline 4 & 20 & 7.40 & 1,329 & 0.011 & 0.003 & 67.27 & 8.96 & 34.03 & 0.0333 & 0.0027 \\
\hline 5 & 20 & 7.22 & 772 & 0.002 & 0.004 & 36.34 & 13.57 & 23.40 & 0.0148 & 0.0013 \\
\hline 6 & 20 & 7,14 & 1,692 & 0.011 & 0.001 & 254.70 & 48.35 & 101.40 & 0.0239 & 0.0008 \\
\hline 7 & 20 & 7.03 & 2,000 & 0.011 & 0.001 & 259.30 & 39.13 & 179.39 & 0.0230 & 0.0021 \\
\hline 8 & 20 & 7.14 & 1,398 & 0.013 & 0.031 & 98.31 & 41.30 & 56.02 & 0.1855 & 0.0062 \\
\hline 9 & 20 & 7.35 & 1,938 & 10.392 & 0.002 & 200.65 & 68.96 & 133.30 & 0.7527 & 0.0550 \\
\hline 10 & 11 & 7.64 & 745 & 0.011 & 0.003 & 1.99 & 9.39 & 2.13 & 0.2104 & 0.4983 \\
\hline 11 & 10 & 7.32 & 2,290 & 0.021 & 0.002 & 350.71 & 86.00 & 173.37 & 0.0016 & 0.0015 \\
\hline 12 & 50 & 7.63 & 899 & 0.160 & 0.003 & 2.16 & 16.96 & 12.76 & 0.3270 & 0.3045 \\
\hline 13 & 15 & 7.14 & 2,890 & 0.142 & 0.010 & 523.19 & 86.87 & 36.87 & 0.0578 & 0.0036 \\
\hline 14 & 20 & 7.61 & 945 & 0.011 & 0.003 & 45.42 & 17.74 & 19.85 & 0.0993 & 0.0066 \\
\hline 15 & 17 & 7.46 & 951 & 0.008 & 0.007 & 36.34 & 12.00 & 15.60 & 0.0339 & 0.0021 \\
\hline 16 & 18 & 7.23 & 1,242 & 0.009 & 0.002 & 108.09 & 31.22 & 25.53 & 0.0107 & 0.0005 \\
\hline 17 & 15 & 7.18 & 1,705 & 0.021 & 0.011 & 242.62 & 79.74 & 71.62 & 0.0083 & 0.0055 \\
\hline 18 & 20 & 7.19 & 742 & 0.015 & 0.001 & 68.42 & 42.70 & 37.58 & 0.0019 & 0.0011 \\
\hline 19 & 20 & 7.31 & 1,482 & 0.002 & 0.002 & 174.78 & 15.04 & 54.60 & 0.0530 & 0.0031 \\
\hline 20 & 20 & 7.26 & 1,225 & 0.003 & 0.003 & 100.61 & 15.74 & 36.87 & 0.0180 & 0.0020 \\
\hline R1 & 100 & 7.55 & 907 & 0.002 & 0.004 & 1.06 & 18.00 & 15.60 & 0.0053 & 0.0012 \\
\hline \multirow[t]{2}{*}{$\mathrm{R} 2$} & 150 & 8.05 & 583 & 0.164 & 0.010 & 1.46 & 58.17 & 1.42 & 0.0429 & 0.0087 \\
\hline & MAC & $6.5-9.5$ & 2,500 & 0.5 & 0.5 & 50 & 250 & 250 & 0.2 & 0.05 \\
\hline
\end{tabular}

MAC- maximum admissible concentration (DWD limits)

Table 2

VARIABILITY OF NITRATE CONCENTRATIONS IN GROUNDWATER SAMPLES

\begin{tabular}{|c|c|c|c|c|}
\hline \multirow{2}{*}{$\begin{array}{l}\text { Depth } \\
\text { of well }(\mathrm{m})\end{array}$} & \multicolumn{2}{l}{$\begin{array}{l}\text { No. } \\
\text { sample }\end{array}$} & \multicolumn{3}{|c|}{$\mathrm{NO}^{-}(\mathrm{mg} / \mathrm{L})$} \\
\cline { 3 - 5 } & 2,11 & Minimum value & Mean value & Maximum value \\
\hline $10-20$ & $10,13,15,16,17$ & 350.71 & 391.24 & 431.78 \\
\hline $20-30$ & $\begin{array}{c}3,4,5,6,7,8,9,14, \\
18,19,20\end{array}$ & 29.90 & 182.45 & 523.19 \\
\hline $40-50$ & 1,12 & 2.16 & 121.43 & 259.30 \\
\hline $100-150$ & R1, R2 & 106 & 39.89 & 77.62 \\
\hline
\end{tabular}

concentrations ranging from 67.27 to $523.19 \mathrm{mg} / \mathrm{L}$. This high nitrate level in groundwater sources used for drinking purpose is of particular health concern because adverse effects can result when nitrate is reduced to nitrite in the human intestinal tract, mainly intestine of infants. The main biological effect of nitrites is linked to their role in the oxidation of hemoglobin to methemoglobin (blue-baby syndrome) which is inefficient for transporting oxygen to tissues. The amount of methemoglobin formed causes the clinical response due to lack of oxygen. Effects range from cyanosis, cardiac arrhythmia, circulatory failure to progressive effects on the central nervous system $[44,45]$. Furthermore, nitrite can react with secondary amines in human stomach to form the highly carcinogenic N-nitroso compounds [41] and exposure to low concentrations of nitrate over a long period of time can favour occurrence of certain cancers such as cancer of the digestive system [46].

In the studied area, the correlation between nitrites concentration and the depth of groundwater sources had revealed that significant nitrates concentrations were recorded on every depth $(0-50 \mathrm{~m})$, excepting for two samples R1 and R2 (considered reference samples) taken from a depth of $100 \mathrm{~m}, 150 \mathrm{~m}$ respectively (Table 2). It was observed that nitrate concentrations decreased with increasing depth of well indicating the existence of pollution from surface sources (e.g. leachate from farmlands, infiltration from unsafe septic tanks, use of nitrogen-based fertilizers).

\section{Bacteriological parameters}

The bacteriological characteristics of groundwater samples are as presented in Table 3. The evaluation of results was made based on the Drinking Water Directive 98/83/EC and the Romanian Law (458/2002, republished in 2011) limits for bacteriological parameters.

All the groundwater samples were positive for heterotrophic bacteria and 50\% have exceeded the maximum allowed limit for CFU. This group of microorganisms provides general information on the presence of pathogenic agents (viruses, bacteria, fungi/ mold and protozoa) in water samples, the risk being proportional to the number of these microorganisms [47]. In the case of faecal bacteriological parameters, respectively: total coliform bacteria, enterococci, Escherichia coli, from the total number of analysed groundwater samples, $63.64 \%$ had positive results in one or more of the investigated parameters (values over the limits allow ed by the regulations) (Table 3). Unfortunately, previous studies have also reported high microbiological contamination in groundwater sources from rural areas in Romania [48].

Total coliform bacteria are widely distributed in nature, being naturally present in soil and on plants and also in the intestinal tract of humans and animals. Coliform bacteria are used as water quality indicators because their presence in drinking water may indicate a possible presence of harmful and pathogenic microorganisms [49]. In some wells, exclusive presence of total coliform bacteria, without the simultaneous presence of $E$. coli, is likely 


\begin{tabular}{|c|c|c|c|c|c|}
\hline $\begin{array}{l}\text { Sample } \\
\text { No. }\end{array}$ & $\begin{array}{l}\text { Well depth } \\
(\mathrm{m})\end{array}$ & $\begin{array}{c}\text { Total heterotrophic } \\
\text { bacteria at } 37^{\circ} \mathrm{C} \\
\left(\mathrm{CFU}^{*} / \mathrm{ml}\right)\end{array}$ & $\begin{array}{l}\text { Total coliform } \\
\text { (CFU/100 mL) }\end{array}$ & $\begin{array}{l}\text { Escherichia coli } \\
(\mathrm{CFU} / 100 \mathrm{~mL})\end{array}$ & $\begin{array}{c}\text { Enterococci } \\
(\mathrm{CFU} / 100 \mathrm{~mL})\end{array}$ \\
\hline 1 & 40 & 40 & 0 & 0 & 0 \\
\hline 2 & 4 & 440 & 542 & 0 & 0 \\
\hline 3 & 30 & 190 & 8 & 0 & 3 \\
\hline 4 & 20 & 340 & 240 & 11 & 1 \\
\hline 5 & 20 & 740 & 8 & 8 & 0 \\
\hline 6 & 20 & 140 & 0 & 0 & 0 \\
\hline 7 & 20 & 530 & 9200 & 27 & 0 \\
\hline 8 & 20 & 560 & 16090 & 542 & 265 \\
\hline 9 & 20 & 636 & 542 & 49 & 0 \\
\hline 10 & 11 & 1470 & 0 & 0 & 0 \\
\hline 11 & 10 & 510 & 0 & 0 & 0 \\
\hline 12 & 50 & 200 & 2 & 0 & 11 \\
\hline 13 & 15 & 30 & 542 & 0 & 1 \\
\hline 14 & 20 & 320 & 348 & 13 & 0 \\
\hline 15 & 17 & 40 & 9 & 0 & 0 \\
\hline 16 & 18 & 10 & 0 & 0 & 0 \\
\hline 17 & 15 & 160 & 9 & 2 & 1 \\
\hline 18 & 20 & 610 & 2 & 0 & 0 \\
\hline 19 & 20 & 2240 & 2210 & 172 & 120 \\
\hline 20 & 20 & 140 & 0 & 0 & 0 \\
\hline R1 & 100 & 77 & 0 & 0 & 0 \\
\hline $\mathrm{R} 2$ & 150 & 127 & 0 & 0 & 0 \\
\hline & $\begin{array}{l}\text { rinking Water } \\
\text { irective limits }\end{array}$ & $\begin{array}{c}\text { No abnormal } \\
\text { change** }\end{array}$ & 0 & 0 & 0 \\
\hline
\end{tabular}

Table 3

VALUES OF

BACTERIOLOGICAL

PARAMETERS IN GROUNDWATER SAMPLES

CFU: colony forming unit

** Abnormal change: $>300 \mathrm{CFU} / \mathrm{mL}$

associated with their origin in the environment. However, the presence of coliform bacteria in analysed groundwater sources represent an indication that other microorganisms, including pathogens can penetrate in the same way into this wells.

Although E. coli is part of the normal human intestinal microbiota, certain strains of $E$. coli can cause severe intestinal and extra-intestinal infections[47]. The presence of $E$. coli in groundwater samples indicates a recent faecal contamination of water, which means an increased risk for the presence of pathogenic microorganisms and intake of contaminated water pose serious health risks of waterborne diseases to the community. Smaller values obtained for Escherichia coli compared to those for total coliform bacteria are due to the fact that $E$. coli is more sensitive to environmental conditions and itcannotmultiply outside the humans and animals body [50]. Positive results for both indicators are a strong indication of recent faecal contamination [12].

The results of bacteriological analysis revealed that the groundwater sources used for drinking purpose in the studied area were contaminated by bacteria, with some high polluted sources and out of compliance with Drinking Water Directive limits. Most of the wells from the area collect groundwater from shallow depths (between 4 and $30 \mathrm{~m}$ ) and the pollution of the phreatic water might be the results of uncontrolled discharges of human and animal waste, infiltrations from unsafe septic tanks and inappropriate agricultural practices in this area, as confirmed by high values of nitrate in these wells, between 67.27 and $523.19 \mathrm{mg} / \mathrm{L}$ (maximum admissible concentration: $50 \mathrm{mg} / \mathrm{L})$.

\section{Antibiotic resistance patern}

Results of the sensitivity of the isolated strains to some antibiotics are presented in Table 4.

Table 4

RESISTANCE LEVELS (\%) IN NON-ENTERIC GRAM-NEGATIVE BACTERIAL STRAINS ISOLATED FROM GROUNDWATER SOURCES

\begin{tabular}{|l|c|c|c|c|c|c|}
\hline Antibiotic & Pseudomonas $s p$. & Aeromonas $s p$. & $\begin{array}{c}\text { Burkholderia } \\
\text { cepacia }\end{array}$ & $\begin{array}{c}\text { Cryseola } \\
\text { luteola }\end{array}$ & $\begin{array}{c}\text { Flaviomonas } \\
\text { oryzihabitans }\end{array}$ & TOTAL \\
\hline IMP & 0 & 0 & 0 & 50 & 0 & 9 \\
\hline TIC & 78 & 75 & 75 & 75 & 50 & 80 \\
\hline PIP & 0 & 0 & 0 & 25 & 0 & 3 \\
\hline TZP & 0 & 0 & 0 & 0 & 0 & 0 \\
\hline ATM & 35 & 25 & 25 & 25 & 0 & 29 \\
\hline CAZ & 4 & 0 & 0 & 25 & 0 & 6 \\
\hline CRO & 0 & 0 & 0 & 50 & 0 & 9 \\
\hline FEP & 0 & 0 & 0 & 0 & 0 & 0 \\
\hline AN & 0 & 0 & 0 & 0 & 0 & 0 \\
\hline NN & 0 & 0 & 0 & 25 & 0 & 3 \\
\hline GM & 13 & 0 & 0 & 25 & 0 & 11 \\
\hline CIP & 4 & 0 & 0 & 0 & 0 & 3 \\
\hline CL & 4 & 0 & 0 & 0 & 0 & 3 \\
\hline
\end{tabular}

*IMP=imipenem, TIC=ticarcillin, $\mathrm{PIP}=$ piperacillin, TZP=piperacillin-tazobactam, ATM=aztreonam, CAZ=ceftazidime, $\mathrm{CRO}=$ ceftriaxone, $\mathrm{FEP}=$ cefepim, $\mathrm{AN}=$ amikacin, $\mathrm{NN}=$ tobramycin, $\mathrm{GM}=$ gentamicin, $\mathrm{CIP}=$ ciprofloxacin, $\mathrm{CL}=$ colistin 


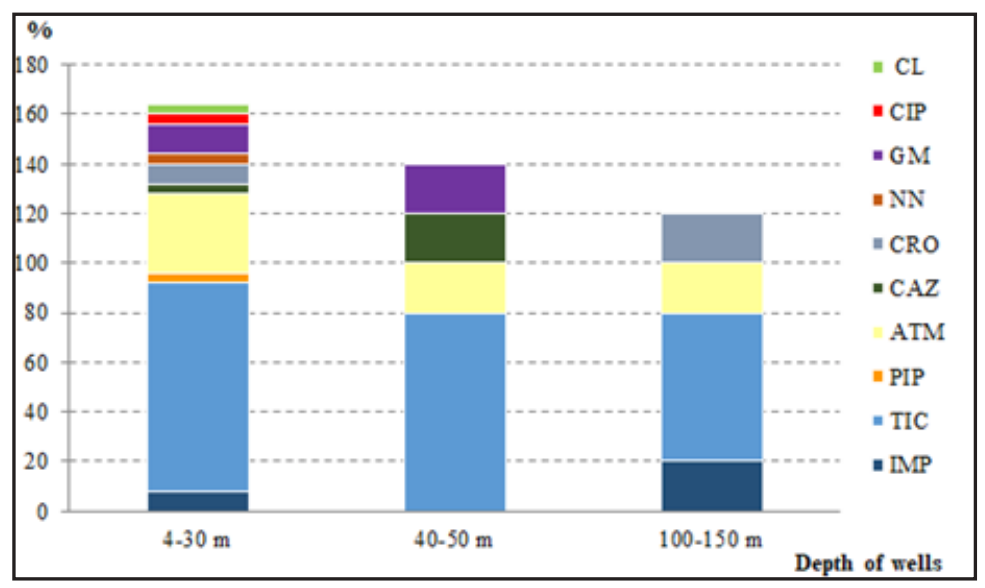

Fig. 2. Distribution of resistance markers in strains isolated from groundwater sources

The resistance rates were interpreted in accordance with the intervals for resistance incidence proposed by European Centre for Infectious Disease Control (ECDC) [51] for clinical bacterial strains i.e: $<1 \%=$ scared; 1 to $<5 \%=$ very low; 5 to $<10 \%=10 \mathrm{w} ; 10$ to $<25 \%=$ intermediate; 25 to $<50 \%=$ high; $\geq 50 \%=$ very high. The BGN oxidazo-positive (Pseudomonas sp., Burkholderia cepacia, Aeromonas sp.) and oxidazo-negative (Chryseomonas luteola, Flaviomonas oryzihabitans) isolated from groundwater sources used for drinking water exhibited very high resistance to ticarcillin (80\%), high resistance to aztreonam (29\%) and low resistance to imipenem (9\%). Resistance to third generation cephalosporins was low for ceftriaxone (9\%) and very low for ceftazidime (3\%). All bacterial strains were susceptible to fourth generation cephalosporins (cefepime). Resistance to other classes of antibiotics (non- $\beta$-lactams) was intermediate to aminoglycosides ( $\mathrm{NN}-11 \%$ ) and low to fluoroquinolones (CIP - 3\%). Most of the Pseudomonas sp. strains isolated from groundwater sources exhibited resistance to one antibiotic (83\%), multidrug-resistance (MDR) (at least two different classes) was found in $26 \%$ of the strains. The constitutive resistance of some species to different $\beta$-lactams, i.e. Pseudomonas sp. to TIC could explain the obtained high level resistance to $\beta$-lactam antibiotics.

The resistance level of the isolated strains to commonly used antibiotics, associated with a high level of bacterial contamination in most of the analysed groundwater sources, indicates a major health risk of waterborne diseases to the local community. In the studied area, it was observed that the level of antibiotic resistance decreased with increasing depth of wells (Figure 2). Taking into account that most of local population use the wells with shallow depth $(<10$ and $30 \mathrm{~m})$ due to accessibility and low well costs, itcould be concluded that the residents are exposed to the risk of waterborne diseases. The high level of bacterial contamination and the presence of antibiotic resistance among bacterial isolates obtained from groundwater sources may be linked to a number of practices that encourage the use of drugs in agriculture and with an improper disposal of human and animal wastes. In natural aquatic environments, such antibiotic resistant determinants can be acquired by non-resistant bacteria and may further serve to resistance dissemination between different bacteria, including to opportunistic pathogens. Previous studies have demonstrated the dissemination of four commonly occurring tetracycline resistance genes (tet $M, O, Q, W$ ) into aquatic environment, from swine lagoons into groundwater $[52,53]$.

\section{Conclusions}

The results of the study revealed that most of the groundwater samples did not meet the parameters of the bacteriological quality, suggesting poor protection of water sources and therefore, pose an important risk to human health. This study also showed the occurrence of antibiotic resistant bacteria in some of the analysed water samples, which further could aggravate the problem of safe drinking water sources in periurban areas. High level of nitrate concentration recorded in most of groundwater samples may be mainly related to pollution, with agriculture and uncontrolled discharges of domestic waste as main sources. Identification of bacteriological and chemical hazards in groundwater sources represents the basic step for elaborating a quantitative health risk assessment of drinking water sources for the population. It is recommended, among others, proper protection of groundwater sources against contamination, including appropriate arrangements of wells (covering, paved perimeter) and improvement of general sanitary condition of the studied area.

Acknowledgments. The work was financially supported by The National Research Program by Projects no. 09060110 and 18260105.1, developed within INCDPM Bucharest.

\section{References}

1.LECLERC, H., SCHWARTZBROD, L., DEI-CAS, E., Critical Reviews in Microbiology, 28, 2002, p. 371.

2.VICA, M., POPA, M., DUMITREL, G.-A., GLEVITZKY, M., TODORAN, A., J. of Environmental Protection and Ecology, 15, no.1, 2014, p. 64. 3.MITACHE, M. M., CURUTIU, C., GHEORGHE, I., LAZAR, V., BUCUR, M., BLEOTU, C., COCHIOR, D., RUSU, E., CHIFIRIUC, C. M., Rev. Chim. (Bucharest), 69, no. 1, 2018, p. 116.

4.ILIE, M., MARINESCU, F., SZEP, R., GHITA, G., DEÁK, GY., ANGHEL, A.-M., PETRESCU, A., URITESCU, B., Carpathian J ournal of Earth and Environmental Sciences, 12, no. 2, 2017, p. 437.

5.MAGGIE, A.M., Environmental Science and Technology, 1, 2007, p. 17.

6.*** World Health Organization (WHO), World Health Report 2002: Reducing risks, Promoting Healthy Life, Geneva, 2002.

7.MARINESCU, F., MARUTESCU, L., SAVIN, I., LAZAR, V., Romanian Biotechnological Letters, 20, no. 1, 2015, p. 10055.

8.MITACHE, M. M., CURUTIU, C., RUSU, E., BAHNA, R., DITU, M., MOLDOVAN, H., HANCU, V., CHIFIRIUC, M. C., Rev. Chim. (Bucharest), 68, no. 3, 2017, p. 566.

9.TATU, A. L., MEREZEANU, N., PANTEA, O., GHEORGHE, I., POPA, M., BANU, O., CRISTEA, V. C., CHIFIRIUC, M. C., LAZAR, V., MARUTESCU, L., Biointerface Research in Applied Chemistry, 7, no. 2, 2017, p. 2004. 
10.IANCU, A. V., CHIFIRIUC, M. C., TUTUNARU, D., ARBUNE, M., GURAU, G., COMAN, G., LAZAR, V., Biointerface Research in Applied Chemistry, 3, no. 4, 2013, p. 599.

11.CONSTANTINESCU, S., PLESCA, C. E., POSTOLACHE, P., LUCA, M. C., Rev. Chim. (Bucharest), 69, no. 1, 2018, p. 236.

12.AMENU, D., Res. J. Chem. Env. Sci., 2, no. 5, 2014, p. 13.

13.TOCIU, C., MARCU, E., CIOBOTARU, I. E., MARIA, C., Ecoterra J ournal of Environmental Research and Protection, 13, no. 3, 2016, p. 39.

14.POPESCU, I., DEAK, GY., DOROBANTU, G., Unsaturated Soils: Research and Applications - Proceedings of the 6th International Conference on Unsaturated Soils, UNSAT, 2014, p. 1119.

15.HEATHWAITE, A. L., JOHNES, P. J., PETERS, N. E., Hydrological Processes, 10, no. 2, 1996, p. 263.

16.MEYLAN, W. M., J ournal of Environmental Toxicology and Chemistry, 23, 2004, p. 22.

17.DEAK, GY., DAESCU, V., HOLBAN, E., MARINESCU, P., TANASE, G. S CSERGO, R., DAESCU, A. I., GAMAN, S., J . of Environmental Protection and Ecology, 16, no. 1, 2015, p. 304.

18.*** Ministry of Environment and Sustainable Development and Ministry of Agriculture and Rural Development, Order no. 1552/743/ 2008 approving the list of localities where there are nitrates from agricultural sources, The Official Gazette of Romania, 851, 2008. 19.*** The Council of the European Union: Nitrates Directive 91/676/ CEE concerning the protection of waters against pollution caused by nitrates from agricultural sources, Official Journal of the European Union, L375, 1991, p. 1-8.

20.*** SR EN ISO 5667-11/2000: Water quality. Sampling. Part 11: Guidance on sampling of groundwaters.

21.*** SR EN ISO 5667-3/2013: Water quality. Sampling - Part 3: Preservation and handling of water samples.

22.*** SR ISO 10523/2009: Water quality standard. Determination of the $\mathrm{pH}$.

23.*** SR EN ISO 27888/1997: Water quality. Determination of electrical conductivity.

24.*** SR ISO 5664/2001: Water quality. Determination of ammonium. Distillation and titration method.

25.*** SR ISO 7890-3/2000: Water quality. Determination of nitrate. Part 3: Spectrometric method using sulfosalicylic acid.

26.*** SR EN ISO 26777/2002: Water quality. Determination of nitrite Molecular absorption spectrometric method.

27.*** STAS 8601/1970: Drinking water. Sulphates content determination.

28.*** SR ISO 9297/2011: Water quality. Determination of cloride. Silver nitrate titration with chromate indicator (Mohr's method).

29.*** SR EN ISO 15586/2004: Water quality. Determination of trace elements using atomic absorption spectrometry with graphite furnace. 30.***ISO 19458/2006: Water quality. Sampling for microbiological analysis.

31.*** SR EN ISO 9308-1/2004/AC/2009: Detection and enumeration of Escherichia coli and coliform bacteria. Part 1: Membrane Filtration Method.
32.*** SR EN ISO 7899-2/2002: Water quality. Detection and enumeration of intestinal enterococci - Part 2: Membrane filtration method.

33.*** SR EN ISO 6222/2004: Water Quality. Enumeration of culturable micro-organisms. Colony count by inoculation in a nutrient agar culture medium

34.*** SR EN ISO 8199/2008: Water Quality. General guidance on the enumeration of micro-organisms by culture.

35.*** Clinical and Laboratory Standards Institute, Performance Standards for Antimicrobial Disk Susceptibility Tests. Approved Standard, 11th ed., M02-A11, 32, no. 1, 2012.

36.*** The Council of the European Union, Drinking Water Directive 98/83/EEC on the quality of water intended for human consumption, Official J ournal of the European Union, L330, Brussels, 1998, p. 32-54. 37.*** Law No 458/2002: Quality of Drinking Water (republished in 2011) (in Romanian).

38.SHRIVASTAVA, N., MISHRA, D. D., MISHRA, P. K., BAI PAI A., India. J . Env Earth Sci., 3, 2013, p. 1.

39.KOLO, B., DIBAL, J. M., NDAKAWA, I. I., European J ournal of Applied Sciences, 1, no. 2, 2009, p. 26.

40.LATEEF, A., KOLAWOLE, L. L., AGOSU, S. O., J ournal of Environment and Earth Science Quality, 2, no. 6, 2012, p. 39.

41.SABO, A., CHRISTOPHER, E. O., European Scientific J ournal J une, 10, no. 18, 2014, p. 466.

42.BOCIORT, D., GHERASIMESCU, C., BERARIU, R., BUTNARU, R., BRANZILA, M., SANDU, I., Rev. Chim. (Bucharest), 63, no. 11, 2012, p. 1152.

43.*** World Health Organization (WHO), Manganese in drinking water. Background document for development of WHO Guidelines for Drinking-water Quality, 2011.

44.MENSINGA, T. T., G. SPEIJ ERS, J . A., MEULENBELT, J., Toxicological Reviews, 22, no. 1, 2013, p. 41.

45.MUNTEAN, S. A., CHIORAN, C., ProEnvironment, 7, 2014, p. 198.

46.J AMALUDIN, N., SHAM, S. M., ISMAIL, S. N.N, Am. J ournal of Applied Sciences, 10, no. 5, 2013, p. 442.

47.KRAUSS, S., GRIEBLER, C., Acatech Materialien, 6, 2011.

48.STOICA, C., VASILE, G. G., BANCIU, A., NICULESCU, D., LUCACIU, I., NITA, L. M., Rev. Chim. (Bucharest), 68, no. 8, 2017, p. 1744.

49.***World Health Organization (WHO), Guidelines for DrinkingWater Quality. Third Ed., Geneva, /http:// www.who.int/ water sanitation health/S, 2003.

50.GELDREICH, E. E., Microbial quality of water supply in distribution systems. Biological profiles in drinking water. CRC Press, Lewis Publishers, Boca Raton, 1996, p. 293.

51.**** European Centre for Infectious Disease Control (ECDC): http:/ /ecdc.europa.eu/en/activities/surveillance/EARS-Net/database/Pages/ maps report.aspx.

52.KOIKE, S., KRAPAC, I. G., OLIVER, H. D., YANNARELL, A. C., CHEESANFORD, J. C., AMINOV, R. I., MACKIE, R. I., Appl. Environ. Microbiol., 73, 2007, p. 4813.

53.MACKIE, R. I., KOIKE, S., KRAPAC, I., CHEE-SANFORD, J., MAXWELL, S., AMINOV, R., Animal Biotechnology, 17, no. 2, 2006, p. 157.

Manuiscript received: 19.12 .2018 